\title{
A Guide and Two Untime Chronicles to Contemplate Rothko's Work
}

\author{
Fernando Echarri ${ }^{1,}$,, Emilio Varela ${ }^{2}$ \\ ${ }^{1}$ University of Navarra Museum, Pamplona, Spain \\ ${ }^{2}$ Official College of Vasco Navarro Architects, Gipuzkoa, Spain \\ Email address: \\ fecharri@unav.es (F. Echarri), evarela@coavn.org (E. Varela) \\ ${ }^{*}$ Corresponding author
}

\section{To cite this article:}

Fernando Echarri, Emilio Varela. A Guide and Two Untime Chronicles to Contemplate Rothko's Work. International Journal of Literature and Arts. Vol. 6, No. 4, 2018, pp. 68-76. doi: 10.11648/j.ijla.20180604.12

Received: August 23, 2018; Accepted: September 7, 2018; Published: October 10, 2018

\begin{abstract}
The experience offered by a museum to a visitor can have different nature and importance for everyone. Each artwork is perpetually sending a message to the viewer, possibly creating an art-person link. This link can provide experiences of great significant power to the visitor. The article below aims to delve into the facilitation of these experiences in the case of the paintings created by the artist Mark Rothko work (1903-1970). Their special characteristics mean that they can be called "Rothko experiences". As a result, a guide to viewing the work, based on the artist's recommendations, has been developed which can facilitate the emergence of these so-called "Rothko experience". Specifically, some of the multiple "realityaesthetical-art" connections experienced between Rothko's work and people whom observation incorporate an aesthetical and metaphysical dimension of reality are presented. To help in the understanding of these profound experiences and the aesthetical education of sensibility, the narrative method is used through two chronicles that gather the experiences lived by the authors in their contemplation of Rothko's work. These chronicles are examples that can help to understand the possibilities of Rothko's contemplative painting. The result is a synthetic study of Rothko work conceptualization, through one guide and the narrative dialectics between two "Rothko experiences" to show his aesthetical way of thinking, represented in his paintings.
\end{abstract}

Keywords: Aesthetic Education, Significant Experiences, Un-Time, Rothko Experiences

\section{Introduction}

One of the main purposes of museums is to promote people's education and provide significant experiences between its visitors [1-7]. In order to achieve this, the museum creates a unique experiential place of variable forms [6] that can help to implement pedagogical innovations [811]. The Navarre University Museum recognizes this innovation and teaching intention and creates a "Significant learning environment" [2]. A place of visual learning, where visitors can use their own strategies and resources to interpret the different aesthetical stories exposed.

The educational program of the Museum, according to Pastor [8], works specifically on the observation capacity and the artwork contemplation through visual education [12]. The emphasis of the program facilitates the creation of significant experiences that contribute to personal development and long-term knowledge [13-15]. It is about encouraging the contemplative experience not only to establish a visual dialogue between "the one that looks" and "the artwork" but to establish an art-person trade relation at the deepest levels of consciousness. To strengthen the relation is necessary passing from the visual connection to the experiential connection. This type of experience is qualified as a Significant Life Experience (SLE) [16-17]. The methodology of narrative experiences can be a methodology to deepen in the understanding of the person-museum relation. "Few studies employ methodological approaches that provide indepth accounts of the museum experience. Narrative methodology is one means by which researchers may access rich accounts of the multi-faceted nature of audience relationships with museums" [18]. Narrative experiences are therefore the preferred methodology used to continue exploring the field. Contemplative experiences from Untitled, 
' a Mark Rothko's work made in 1969 that belongs to the American abstract expressionism movement are taken as examples. [19] The artwork is today in the Navarre University Museum collection (Figure 1).

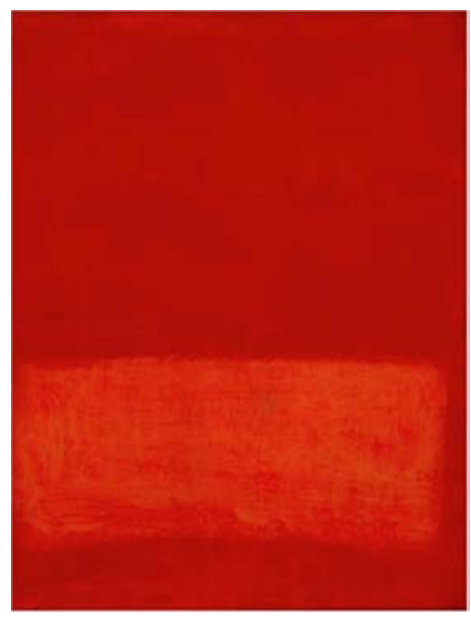

Figure 1. Untitled, 1969. Marc Rothko. University of Navarra Museum.

\section{Possibilities of Rothko's Paintings Contemplation}

Rothko's work implies a before and an after in history of painting [20]. His style, qualified as dramatic [21] has characteristics that increase the contemplation possibilities [22]. Rothko worked to "create an experience that the viewer has to live from his own point of view without any distractions" [23]. This experience "is a crucial element in the investigation of the possible terms and conditions for the encounter with Mark Rothko's late classical paintings" [24]. His work makes possible those activities of "meditational look" [27] because through his "colour fields" [25] he is able to create undefined, timeless, and infinite atmospheres that in a personal way can generate powerful emotional experiences. This is what happened to Dominique de Menil: "So I just looked. O miracle, peace invaded me. I felt held up, embraced, and free. Nothing was stopping my gaze. There was a beyond." [26]. His paintings can create "an intimate and human relation between painting and viewer and of making paintings, which involve the viewer in such a way that she is experiencing herself being inside the painting" [24].

Motherwell also thinks that those experiences are so deep and immersive that "if Rothko had never existed, we would have never known some of the emotional possibilities in modern art" [21]. He agrees with the meaning of Rothko statement: "A picture lives by companionship, expending and quickening in the eyes of the sensitive viewer" [26]. This atmosphere around the painting covers the viewer with what Rothko himself called his painting ideal purpose: "the easy

1 The Museum have multiples collections, among them, the one that gave Maria Josefa Huarte [48] that includes the painting Untitled (1969) by Mark Rothko (1903-1970) that belongs to the American abstract expressionism movement. expression of a complex idea" [27]. That is why his paintings are considered good for meditation [27] and thinking because the simplicity with which he represents complex ideas makes possible a succession of "experiences": "Fullness and emptiness, openness and closeness; and between how the canvas looks at the beginning of the viewing encounter and how it looks at the end, after the eyes tire and begin to produce afterimages" [28]. Rothko knew about the potential of his paintings, the possibility to expand or contract in many ways, depending on the viewer's look, extra or introspective [29]. Rothko painting is able to connect the macro and the microcosms [25] creating an infinite expansion impression [30]. That is why it is possible to apply the Hooper-Greenhill thinking: "The perceived thing [...] is rather a totality open to a horizon of an infinite number of perspectival views, which blend with one another according to a given style which defines the object in question." [5]

Muñoz believe that: "Rothko's canvas exposes themselves in a soft show of colours, looking for a connection with the viewer $[\ldots]$ it's an experience where different meanings slowly scatter to reach a perfect and total union with the creation" [27]. His paintings reach an emotional and spiritual dimension [25] as they search for the direct transmission of a similar feeling of the "religious" through colours [27]. A spiritual-mystic-religious perspective is embraced [31]. Rothko himself made this statement: "People that cry before my paintings live the same religious experience as me painting them" (Baal-Teshuva, 2003, p. 57). While contemplating his work, we can feel these "vertiginous feelings prompt questions about the meaning of life and the fragility of mortality" [31]. For Arya: "Contemplating Rothko's artwork is a spiritual journey" [31]. That is maybe why his paintings "touch the spirit of the spectators" [21] questioning their transcendental or spiritual intelligence. [3233]

In the end, concerning the contemplation of one Rothko's work, for those who are in symbiosis with his vision, "the experience can be akin to a tracelike rapture" [34]. Furthermore, authors name this experience, the "Rothko experience", it can be physical, emotional, intellectual, or spiritual [28]. For the anthropologist Nelson Graburn [1] this type of experience can be compared with what he called "reverential experience": "A personal experience with something higher, more sacred, and out of the ordinary than home and work are able to supply". This "Rothko experience" has "complex affinities between relaxation techniques" [28], even though it implies an active contemplation behaviour. This is the reason why Rothko's painting contemplation can achieve making an experience "positive and memorable in the meantime" [1].

Hooper-Greenhill [5] and Hein [3] way of thinking can be indeed applied to Rothko's paintings, when they explain that each piece of art has "its own life". A life, however, given individually by every visitor, interpreted and defined by perspectives they grant to the contemplated object [5]. In the same way, Rothko said: "A canvas lives before a sensitive viewer, whose conscience is developing" [29]. Considering 
all these reasons, it seems that the "Rothko experience" can be seen as a SLE [16-17] for having common points, as being "considered to be transcendental experiences" [35], and sometimes, they can be engraved in the heart for life [36]. They produce in people a response of a great level of intensity, perhaps an emotional and spiritual state [37] of an unusual power, rarely experienced and therefore remembered and perhaps unforgettable [36]. In the end, SLEs can act like "Significant Influences and Formative Experiences" [38] refer SLE as characterised by "absorption in the moment and a sense of timelessness". The "Un-time" finds its way and flourish in those experiences [39].

\section{Guide to Contemplate Rothko's Work}

From Rothko's observations of his own work, of how he looked and painted his canvas, of the space distribution in expositions, and his way of thinking about the light of his paintings (for he was meticulous with those questions), has been created a short guide for the aesthetical education through the contemplation of his artworks. A sensitive view that not only has as purpose to perceive the beauty, but also to make possible the "Rothko experience", to experiment beyond images and meanings, limits of space, light and conscience. Following this idea, this is a guide to Rothko's artworks contemplation, which collects the personal principles of the painter. In the end, it aims on shaping each observer, creator and artist's aesthetic and philosophy metaphysical- view.

1. Trust in the artwork. This trust in Rothko's work is required to make the experience possible, in the meantime, Rothko trusts us. Empathy is crucial in the encounter with the painting [21]. So as Rothko trusts "the minds of sensitive viewers, who are free of any understanding conventions", contemplation requires a total trust from the viewer, he must open his eyes, his mind and must focus, to let it flow through him. This is the only way for the artwork "to make us feel emotions, to move us, to push us out of ourselves." [21]

2. Why is the painting sized like this? For Rothko, the size is a key to facilitate the experience. "Painting a small canvas means that the viewer is in the experiential comfort zone, as it implies sensing the experiences from every direction, as with a magnifying glass. Painting a big canvas place the viewer inside it as if he is trapped in it, making it difficult to dispose of it."

3. Why the artwork is placed this way? Far from being a detail, placement is fundamental to Rothko. The distance between the canvas and the ground must be taken in consideration, "I hang the paintings low, and for the bigger ones, as closer to the ground as possible, as they were painted this way." [21] (Figure 2)

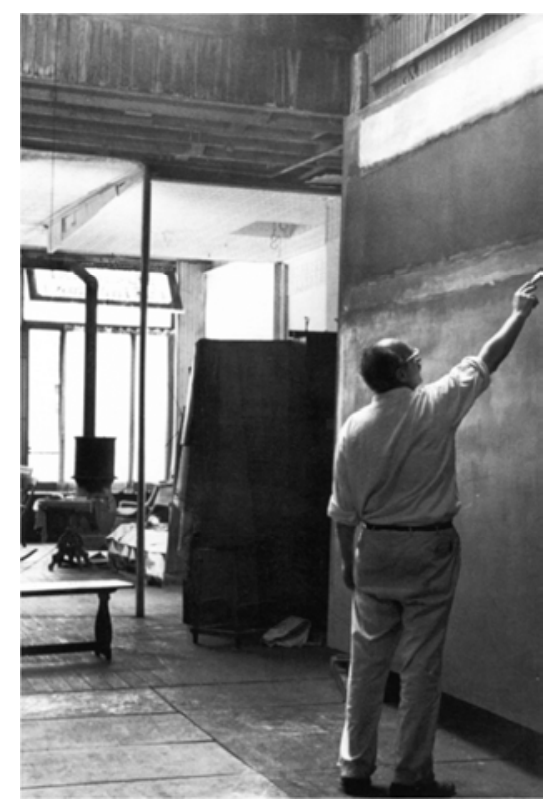

Figure 2. Rothko in his studio on West 53rd Street, around 1953. Photo by Henry Elkan [46].

4. Where must I stand? The viewer's placement can influence the experience: "Rothko thought that the ideal distance to contemplate was 17.7 inches (45 centimetres) (Figure 3). This way, the viewer engaged with colours, can experiment every intern movement, and the absence of extern limits." [29].

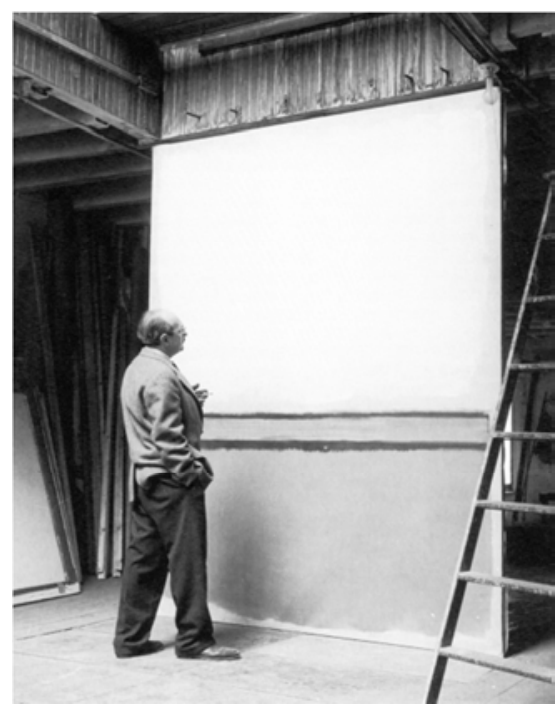

Figure 3. Rothko contemplating the painting $N^{o} 25$ (1951), c. 1952. Photo by Kay Bell Reynal [50].

5. How is the light chosen? To reach the emotional effects Rothko wanted for his paintings, light is an important factor: "Rothko demanded a low light, to give a mysterious atmosphere to his paintings [...]" [29].

6. How should I considerate space in the frame? The space of the frame must be of our attention and interest. "The space it's a philosophical base for a frame, generally it determines the functioning of the plastic elements inside" [40]. The view of the space must be 
deepened not only in the two common dimensions, how high and how wide the painting is, but we must look for new dimensions. Rothko not only wanted us to discover the third dimension of his paintings, but also to experiment the space created by his canvas depth: "concerning space, depth was the most interesting for Rothko" [21].

7. Shall I educate my gaze? It's not easy to experiment a "Rothko experience" without a deep, analytic and wise observation. The evolution in the painter's observation capacity, agreeing with a general sight theory, could be summed up this way: in principle, the observation that consist in going beyond the frame surface, looking for images or figures, forms and colours, is a subjective observation of an object. This object is the frame as a place of expression and representation of what's symbolic and beautiful. The intimate relation between viewer and observed begins when, in the observation appears meanings and meaningful -signification-, conscience -and not intelligence-, and that a progressive and continuous path reveals the clarity and depth of light and space. Both meet in the ideal place for an aesthetical and sensitive experience. When both necessity and spirit are given, then comes "the guarantee of a real trade." [29]

8. For how long should I contemplate an artwork? There are no real rules concerning the time of contemplation. However, and ironically, you need enough time to reach the un-time. It means contemplate until the experience erase all sensation of time. Within the "Rothko experience", contemplation means to experience the un-time [41]. To reach this point, the observer shall adopt a comfortable position, this way, discomfort won't interfere with the experience. Absorption from the canvas of the viewer's most intimate personality, his total delivery to it, through his own being, make him reach the un-time. It can happen and be perceived that time continuity is broken to get to timelessness.

9. What happen for the physical and metaphysical? The contemplation possibilities offered by these artworks are not only physical but also metaphysical. Paintings created from spatial and floating forms and colours, that expand or contract in all directions, to the interior or exterior of the frame shapes. Blurred and transparent combinations of forms, that create different environments in which conscience can feel, think, and meditate. This space contains light, with all its different levels of transparency and density, its main dimension is depth. A metaphysical environment dimension, that allows us not only to "make the dark, clear or metaphysically to make the far, close". [21] but also to reach new levels of conscience: "To go from dark to clear, to make it float through my human and intimate understanding." Vega said [21]: "Rothko's metaphysic does not give up on meanings, for they are the way to express and perceive his emotions". In the end, Rothko went from the metaphorical and symbolic shapes of figurations and meanings to go to the metaphysical shapes of absence and silence, this is what he changed in his process. It supposed that, the frame went itself from a symbolic space of representation to a concrete place for the metaphysical experience. "They are not frames, they are things." [21].

10. What's a Rothko experience? It's a contemplation experience that leads us to a personal metaphysical experience. This way, we reach a new point of view, and a new space, where suddenly, the attentive consciences energies wake up, making possible some transformations for the sensitive observer. It can be about an experience more sensitive than conceptual, more emotional than visual. It is closely related to emotions and perceptions, like plastic realities of gravity, lightness, buoyancy and expensiveness, spatial and visual limits that Rothko's work, the body of his paintings, reach with colours and forms, light and space, transparency and depth. This experience can help us find meanings for our own being. It can be an experience rather different, because "I" does not explain the experience, the experience explains the "I".

\section{Spatial-Temporal Approach for the "Rothko Experiences"}

Indeed, it is possible to work on this trade at a young age. That is why, museums have a crucial importance. Museums must show real experiences about the works, to fully connect the viewer's perceptions and emotions to the artist's ones, and go further than the work signification, the artist biography, and what art history, and critics said about it. "Rothko wanted the viewer to feel his point of view and experience" [21] (Figure 4)

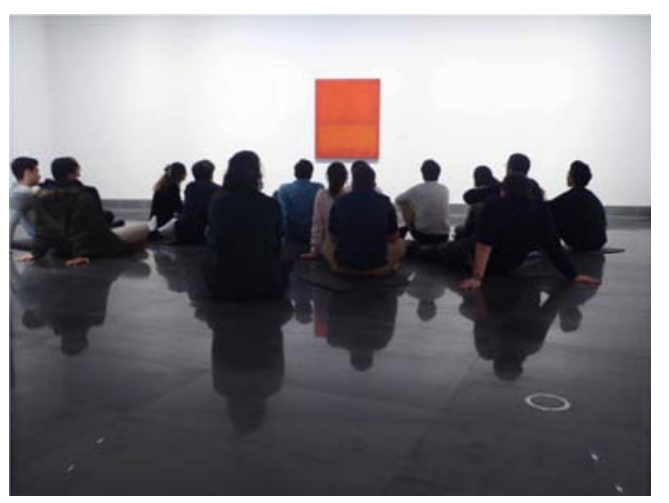

Figure 4. Group of visitors to the University of Navarra Museum contemplating Rothko's painting.

Even though the paintings are surrounded by the frame, time emerge from the accumulation of distinct fields of colours. What's more and more interesting from his work, is precisely the relation between this dark background (light and transparency superposition) and the possibility of slow timing for reflection. In another way, the link established 
between the depth dimension (in the artwork) and the experience duration (for people). The sight extends with the immobile movements of the painting, and the vibrations of the light. It's in the frames depth that life finds its way, that these "bodies of light" beat [42] the dark and transparent heart of the matter.

Each one of his frames is the "incarnation of the emotion, created by layers of material and time" because Rothko's paintings are about "emotions directly coming from life experiences". "When being in front of a Rothko's work, time stops, freeing us to build our own poetical relationship with it" [42].

His artworks are not only directed to intelligence, they are places in which consciences meet. It supposes a different view to what's beautiful, and what's hidden, to landscapes and infinite (exteriority), or to a definitive vision of limits and emptiness, immobility and absence (interiority) which is not imagination but spatial conscience.

\section{Metaphysical Conscience and "Aesthetical Education of Sensibility"}

The link created is not complete if the sensitive dimension is not considered, if it dispenses from the aesthetical observation. "We must teach observation" César Manrique used to say, calling for changes to the responsibility of the eye in educating the gaze [43]. It's precisely through art that life transforms itself in every way.

The conformation and education of observation must go beyond the basic physical aspect. Like Whitman ${ }^{2}$, Oteiza thinks that it's necessary to learn the observation of the invisible. He means that "what's visible is sacred, and the invisible is a hidden sacred, a deficiency in our vision" [44]. It's with the education of our sight that we can reach possible messages that matter encloses in all of its dimensions.

An educated sight let us have an intern vision, because the vision of conscience is nothing else than looking outside to see inside. This means that these artworks are not windows or mirrors to see landscapes or masks neither objects nor what looks like objects, instead they are blinded ${ }^{3}$ walls and abysses that impose limits to space and light, to make the essential happen for the conscience. Artworks that change the communication order between canvas and viewer, which differs from the basic exchange of information and aesthetic pleasure. It makes possible a metaphysical ${ }^{4}$ communication, or $\mathrm{a}$ in communication with objects in order to reach the

2 "My body done with materials, my sight done with my material eyes, proved to me this day beyond cavil that it is not my material eyes which finally see." [49]

3 Talking with Fisher (John Fisher, Harper's journal director) he admitted that the source he had unconsciously had for his frames Seagram was the spatial sensation produced by the facades Michelangelo had created for the Laurentian Library staircase: "it provoked the exact sensation I was looking for, the visitor had the impression to be trapped in a place where doors and windows were all on board." [29]

4 Vega [21] remembers Merleau-Ponty words when saying: "the whole painting modern history, all its efforts to separate from illusionism and obtain its own dimensions, have a metaphysical meaning." clarity and depth necessary for things and conscience.

Rothko's paintings are not basic frames, but places to experience. "I have made a place" [21], he said while referring to murals of Seagram restaurant. Because his artworks really have these metaphysical dimensions that fit inside houses, galleries and museums, and demand all senses, not only sights. His painting achieves in an organised mix of forms and colours, "Mutliforms" and "Sectionals", deep perceptions of space and light that transform in intimate emotions like music ${ }^{5}[40,45,21]$ and architecture $^{6}$. [46]

All of this makes a Rothko artwork presence in a museum an event. Either with one or more artworks, a new visibility is created, a new space, where attentive consciences energies immediately wake up, making possible transformations for the sensitive observer, which the museum is in charge of propitiating through experiences and communication with the artwork.

In fact, an aesthetical and developed education of a sensitive observation gives access to a new level of vision, where it is possible to gain a better depth in contemplation. This is nothing but personal conscience identification with exterior reality, it consists in an emotional interiorization of what can be seen, alongside a "space conception deepening process" [21]. Artworks as Rothko's ones, can guide sensitive and attentive viewers through colours and forms of extern spaces and lights, to the clarity and depth of their thinking and conscience. "The object of contemplation, or observation, is the one that created, with the sight, an exit which has no more path than the one that comes back in place." [21]

These canvases ${ }^{7}$ of colours and forms, that then will join his murals as in "Rothko Room" and the "Rothko Chapel" (Figure 5), arise from the depth of space, where the point of orientation of the spectator to the painting is given by the light atmosphere created by the artist. To Rothko ${ }^{8}$ the environment is not something abstract, is an idea or a concept like beauty or perspective: "my art is not abstract, it lives and breathes" [47], it's material, and corporeal like air: "Rothko calls air, space" [21], that contains light in its different levels of density and transparency, and which principal dimension is depth. A metaphysical dimension of nature that allows reaching the deepest levels of consciousness.

5 Relationship between Rothko and music were highlighted in 1963 by Juan Eduardo Cirlot [45], where he talked about his paintings as "visual chords". It had always been an important theme for the artist, which were later addressed by critics.

6 For Rothko, integrate in his artworks spaces from architecture was crucial. Not only the positions were precise regarding spaces and walls of the rooms, the best enlightenment was chosen as well. It is possible to say that the first important transformation coming from Rothko artworks is the sensitive perception of architecture.

7 "My new fields of colours are things, I put them on surface. They don't reach borders, they stop before." [21]

8 Rothko made a clear difference out of materials: the illusion and the physical. For the first one, the referential point is out of the frame itself, while in the second, he says that a new being has been created in terms of material. [40] 


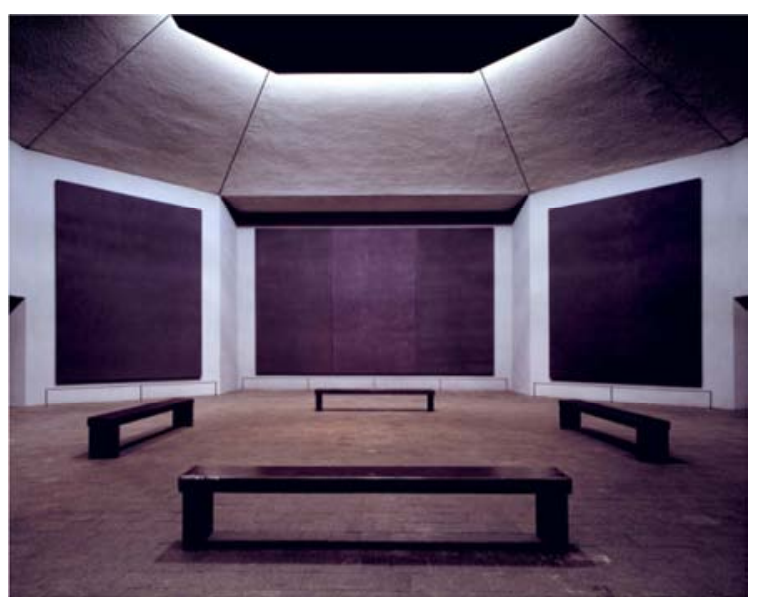

Figure 5. Rothko Chapel, Houston, TX. Photo by Hickey-Robertson.

Developed artworks with metaphysical dimensions, like in Rothko's paintings, suppose that the artist has to create with his work, places in nature and in life where elements and forms build new spatial realities, available not only for senses but for consciences. Empty places, which immobile spaces had been activated to be receptor and which have as a purpose, when in life and nature, to define limits in which consciences can move, or, in other words, artwork-person relations with their own being.

To reach a way of thinking that will not only serve to art, a metaphysical thinking, Rothko's artwork entered in a process of progressively silence. He abandoned the very first representations of masks and myths making forms and materials weaker. It consisted in giving to the painted body, a set of colours, and a basic organization, that superimposed as happens in a landscape, freeing the environment and the light from the energy contained inside. He reached a painting about emptiness and transparency, which aesthetic nature became more receptive and active concerning its metaphysical dimensions, becoming in the place for conscience.

\section{Dialectics of Two "Rothko Experiences"}

When we face one of the Rothko's "multiforms" canvas contemplation, experiences can emerge. These can be of diverse rank and intensity. When they have a significative rank, we can talk about the SLE mentioned above, the "Rothko experiences". This study is based on the experience the authors lived during Rothko's work contemplation. As other critics did before when qualifying the artwork as experiences they both agreed on some aspects that they were able to isolate, detect and define as "Rothko experiences". Those experiences are expressed through poetical language, something significant as an attentive observer will experiment sensations and emotions that are hard to express with a logical and instrumental idiom. There's difficulty in communicating what has been lived and experienced. We think that the one way to make people understand the experience lived while observing Rothko's paintings is to describe them through language. We as searchers need to objectify the experience, but for a common spectator sensing the artwork can be enough. Rothko wanted and achieved the transmission of emotions through colours. Each one of us has narrated this contemplation experience, this aesthetical event through two chronicles that create dialectic, following Everett \& Barrett [18] methodology.

\section{Chronic 1. Vivid colours clouds in the sad blue skies}

The masses of unmoving light emerge like embers from intense colour, these clouds of destruction as faces or landscapes forgotten in time, and an immense suspension of emptiness of absolute stillness shakes the figuration of the invisible, erased or asleep images from the mistake of memory, hidden unrecognized forms of the slow liberated matter by desire: are from the dream of the big transparent spheres, that are from a superior order, almost a crime great beyond beauty. The skies are finished and destiny is not the promised salvation neither figured by love or hope; nothing exists in the blue memory of the eyes except the masks of emptiness and the white lamps of extinction. And all the clarity of the world waits to be disappeared through opened eyes, while an arid desert grows like the night in a place dug by absence. The lights cultivated in silence, are the ones that extend their transparent harvest upon the fields of colour: the secret brightness that burns slowly without the sun, like flames of fog in transparent fire and then moves forward. In the end, from a transparent bottom, in solitary invasion to the limits of a great silence crushed against air, between the confusion of the colours and the dizziness of the edges and in the vertex of the light. Where everything is resignation of content or settlement of sense, and every visible figure is made of smoke and silence; every unfinished or mutilated body by the temptation of pain is the only pleasure in the sacrifice of the pallid flesh: only instant creature, fragments liberated by light.

Be able to occupy the intimate spaces of abandonment where forms are lose and their meanings weaken; and the naked beauty without dresses is in reality the terrible lucidity of the shadows. Where no object will ever be deformed by the light of an idea, no image will be deformed by an ideal. And looking consists in denying any prominence, in hiding everything behind the shadows of the nothingness and the stains in the soul.

Then, the absence of sings and gestures in the external glace: the cruelty of the eyes that search for beauty and die constantly in the infinite space. Also, the thought that reduced itself to the double knowledge of the blood: the bloody light and the luminous flesh. The grey and static brain that comprehends, at last, the red signs and the abstraction, is the complete solitude: a definitive world where the extinction is the only light and the destruction of the true love. Bodies of dangerous colour of nothing; consumed souls in the massive light of hells. Certainly, at the end arrive to a space without contemplations, where looking ends up above a dull wall compound only by a unique motionless image.

Chronic 2. The colour of darkness in the untimely 
The liturgy of the mystery of colour begins and ends with Rothko. In the liturgy is manifested the artist generation and evolution from the total and complete nothingness. In this ceremony the patient gaze transmits the transubstantiation: in each point of the canvas the colour catch, penetrates and reduce the space, stealing the time it contains, conceding the immobile eternity to each brief instant. From nothingness of space and time emerge a perpetual transmigration towards oneself. In this internal trip of denial, the light becomes clearer until the darkness is discovered, that blackens to a point that it is perceived as clarity. Nothingness is then transformed into something useful and complete, covering the spirit with tinted meat: the alchemy of colour is produced. The nothingness is now everything. In this process the colour reduces itself to its elemental particle and each grain is a powerful seed that grows and destroys our strength into invisible pieces, it dissolves us. Finally defeated, the humility now repairs itself with a combination of an unexpected colour, infinitely angular, perfect and clean.

Then the new image divines to be an enabler aurora that claims to be comprehended. The whole painting attracts us, and when already committed and perplexed it reveals to us an invasive threatening gesture. As soon as it questions ourselves with a friendly proximity, it dispatches us sharply, despising us with unaccepted manners. Despite the resentment, under its talkative hypnosis, eyes, stomach and heart get together once again to connect the path to reason and fulfil it.

Through reason the glance explores, believes in finding something, rambles and searches again. Finally, the mind catches the colour. Discovering it again a thousand times, digest and accepts the game. The contemplation of the colour already saturates every particle of the mind and drags it to the profound paths of light. It is precise to move forward: the eyes set off, learn to look backwards, and travel through a limit that is neither limit nor sense. Beyond the indecisive look, they find their new purpose, connect and finally, incredulous, recognize the metaphysical dimension. The colour learner has doctorate in the gaze.

Without hesitating the colour continues his wise process and now shows the fullness to light the pure emotion and without mediation, administrate it. This time his expression is the same as the impression and is accepted naturally. The colour is now a fire atlas that holds the world in the no time. Recreates itself in his fleeting dynamism in a lighthouse of volatile dark light. Sometimes it turns and generates space and possibility, although never time, in a regression of the end that plays its eternal beginning. Meanwhile, each form grows and covers an immeasurable enigmatic land and prays that wants it all for itself, for, once well done, disintegrate it with indolence and without remorse. Finally, the reached utopia loses here sense to go back to its own beginning: of the infinite landscape unlimited by the dot. Always arise from them paths without end that search the same itinerant destiny. After being able to cross barriers, the untimely impose himself, rides in the expandable past, present and future plain, dragging them. Little by little we go back to our reality, look away. But no second has passed and we already miss it. Resigned we go back to our chores. Everything changes, but him, unconnected to space and time, inalienable, persists.

\section{Conclusion}

Rothko's work is about the progressive path from the physical and formal to the spatial and metaphysical, or from the painting as a visual object and as material image to the painting as emptiness and immobility. Meaning, the artist goes from considering the painting as matter (material form) to focus on its energy (spatial form). In the end is about the shift of a painting that uses colours and forms in time, to a painting that reflects its dissolution in the space of the untimely.

Rothko manages to overcome the aesthetic of the beauty and the ideal with a motionless and empty aesthetic. He shifts from the perspective of the artwork as an aesthetic construction of the mask and the landscape for other of silence and limit, from the representation of the object and the symbol and from the expression of the subject, to the creation of limits of vision. The artist proposes a space and light, where the silence and the absence activate receptive spaces in consciousness.

In the same way, the aesthetic thinking in Rothko's artwork develops from the symbolic image of nature and life to the metaphysical consciousness of reality and existence, a change from a "figurative and abstract" thought to one about the "metaphysical and absolute". The vision of nature passes from being viewed through the imagination to be sensed with the consciousness of limit.

The development of a Guide for the contemplation of Rothko's artwork contributes to form and educate the way in which a Rothko's painting should be observed and experienced. It facilitates the dialogue and interpretation of the complexity of his painting and conceptually supports the different achievable narratives. It contributes to the analysis, reflection and understanding of the possible "Rothko experience".

\section{References}

[1] Falk, J. H., \& Dierking, L. D. (1992), The Museum Experience. Washington: Whalesback books. p. xv, p. 15, 157.

[2] Hein, G. E. (1998), Learning in the Museum. New York: Routledge.

[3] Hein, H. S. (2000), The Museum in transition. A philosophical perspective. Washington: Smithsonian books, p. 58.

[4] Hein, G. E. (2012), Progressive Museum Practice. John Dewey and Democcracy. Walnut Creek, California: Left Coast Press, Inc.

[5] Hooper-Greenhill, E. (2005), Museums and the interpretation of visual culture. New York: Routledge, p. 15, 3. 
[6] Falk, J. H. (2009), Identity and the museum visitor experience. Walnut Creek, California: Left Coast Press, Inc.

[7] Burnham, R., \& Kai-Kee, E. (2011), Teaching in the art Museum. Interpretation as experience. Los Angeles, California: Getty Publications.

[8] Pastor, Mª. I. (2004), Pedagogía museística. Nuevas perspectivas y tendencias actuales. Barcelona: Ariel Patrimonio. p. 44.

[9] Hooper-Greenhill, E. (2007), Museums and Education: Purpose, Pedagogy, Performance. New York: Routledge.

[10] Filippoupoliti, A., \& S. Sylaiou. (2015), "Museum education today: creative synergies and pedagogic innovations in multicultural contexts". Museum \& Society, 13 (2), pp. 119 122.

[11] Kristinsdóttir, A. (2017), Toward sustainable museum education practices: confronting challenges and uncertainties. Museum Management and Curatorship, 32 (5), pp. 424-439.

[12] Berger, J. (1972), Ways of seeing. London: Penguin books.

[13] Ausubel, D. P. (1976), Psicología educativa. Un punto de vista cognoscitivo. México: Trillas.

[14] Novak, J. D. (1977), A Theory of Education. Ithaca: Cornell University Press.

[15] Novak, J. D., \& Gowin, D. B. (1984), Learning how to learn. Cambridge: Cambridge University Press.

[16] Chawla, L. (1998), Significant Life Experiences Revisited: a review of research on sources of environmental sensitivity. Environmental Education Research, 4 (4), pp. 369-382. doi.org/10.1080/1350462980040402.

[17] Chawla, L. (2001), Significant Life Experiences Revisited Once Again: response to Vol. 5 (4). "Five Critical Commentaries on Significant Life Experience Research in Environmental Education". Environmental Education Research, 7 (4), pp. 451-461. doi: $10.1080 / 13504620120081313$.

[18] Everett, M., \& Barrett, M. S. (2009), Investigating Sustained Visitor/Museum Relationships: Employing Narrative Research in the Field of Museum Visitor Studies, Visitor Studies, 12 (1), pp. 2-15, DOI: 10.1080/10645570902769084.

[19] Calvo, F. (2003), El Expresionismo Abstracto en las Colecciones Españolas. Segovia: Museo de Arte Contemporáneo Esteban Vicente.

[20] Blanco, S. (2014), El arte y lo sagrado. Su encarnación en la Capilla Rothko. Ilu. Revista de Ciencias de las Religiones, 19, pp. 47-64.

[21] Vega, A. (2010), Sacrificio y creación en la pintura de Rothko. La vía estética de la emoción religiosa. Madrid: Siruela, back cover, p. $9,10,73,90,130,89,75,83,72,62,77,86,65,126$, 128. ISBN978-84-9841-366-3.

[22] Khaled, K., Wald, H. S., \& Castel, O. C. (2014), The use of abstract paintings and narratives to foster reflective capacity in medical educators: a multinational faculty development workshop. Med Humanit, 40, pp. 44-48. doi:10.1136/medhum-2013-010378.

[23] Spadaro, A. (2008), Mark Rothko: A Painter Below the Threshold of Light. Humanitas, 13 (51), pp. 541-557.
[24] Christensen, R. (2017), Mark Rothko: Art as an Experience. The Significance of Interaction between Painting and Viewer in the Rothko Chapel. RIHA Journal, 183, URL: http://www.riha-journal.org/articles/2017/0183-christensen, URN: [see metadata].

[25] Chave, A. C. (1989), Marc Rothko. Subjects in abstraction. New Haven and London: Yale University Press, p. 6, 107.

[26] Nodelman, S. (1997), The Rothko Chapel paintings. Origins, structure, meaning. Austin: University of Texas press, p. 9, 39.

[27] Muñoz, R. (2008), Apunte sobre Mark Rothko: "La tela nos ha hablado". Fedro, Revista de estética y teoría de las artes, 7, pp. 85-95.

[28] Phillips, G., \& Crow, T. (2005), Seeing Rothko. Singapore: Getty Research Institute, p. 1, 2, 6, 7.

[29] Baal-Teshuva, J. (2003), Mark Rothko. Cuadros como dramas. Colonia, Germany: Taschen, p. 57, p. 31, p. 46, p. 50, p. 91, p. 62 .

[30] Gonzalo, J. (2016), Espacios de meditación: Mark Rothko y Morton Feldman. Revista judía de la cultura, 106, 20-23.

[31] Arya, R. (2011), Contemplations of the spiritual in visual art. Journal for the Study of Spirituality, 1 (1), 76-93. doi:10.1558/jss.v1i1.76.

[32] Gardner, H. (2010), La inteligencia reformulada. Las inteligencias múltiples en el siglo XXI. Madrid: Paidós.

[33] Wolman, R. (2001), Thinking with your soul. Spiritual intelligence and why it matters. New York: Harmony books.

[34] Janson, H. W., \& Janson, A. F. (2001), History of art. Harry Abrams: New York. In: Phillips, G., \& Crow, T. 2005. Seeing Rothko. Singapore: Getty Research Institute, p. 817.

[35] Williams, K., \& D. Harvey. (2001), Transcendent experience in forest environments. Journal of Environmental. Psychology, 21, 249-260.

[36] Vining, J., \& M. S. Merrick. (2012), Environmental Epiphanies: Theoretical Foundations and Practical Applications. The Oxford Handbook of Environmental and Conservation Psychology. New York: Oxford University Press. doi:10.1093/oxfordhb/9780199733026.001.0001.

[37] Hawks, S. R. (1994), Spiritual Health: Definition and Theory. Wellness Perspectives, 10 (4), 3-11.

[38] Palmer, J. A., Suggate, J., Robottom, I. M., \& Hart, P. (1999), Significant life experiences and formative influences on the development of adults' environmental awareness in the UK, Australia, and Canada. Environmental Education Research, 5 (2), 181-200.

[39] Echarri, F. (2016), Environmentally significant life experiences: what do they have in common? Proceedings of ICERI2016 Conference14th-16th November 2016, Seville (Spain). ISBN: 978-84-617-5895-1.

[40] Rothko, M. (2004a), La realidad del artista. Filosofias del arte. Madrid: Editorial Síntesis, S. A., p 89, p. 79.

[41] Han, B.-C. (2016), El aroma del tiempo. Un ensayo filosófico sobre el arte de demorarse. Barcelona: Herder Editorial, p. 13. 
[42] Scully, S. (2000), Cuerpos de luz. Mark Rothko. Pasajes. Revista de pensamiento contemporáneo, 2, 75-83.

[43] Gómez Aguilera, F. (1990), Arte y naturaleza en la propuesta estética de César Manrique. [Art and nature in the aesthetic proposal of César Manrique]. Atlantica, 58-63. Las Palmas de Gran Canaria: Centro Atlántico de Arte Moderno. ISSN 11328428.

[44] Merino, J. L. (2008), Habla Oteiza. Bilbao: Editorial Avance Proyectos. Colegio Oficial de Arquitectos Vasco-Navarro, p. 40.

[45] Cirlot, J. E. (1996), Rothko y Scriabin: paralelos entre colores y sonidos (orig.: La Vanguardia, 24 de agosto de 1963). Catálogo de la exposición Mundo de Juan Eduardo Cirlot, IVAM Centre Julio González (19 de septiembre al 17 de noviembre de 1996). Valencia: edición de Enrique Granell Trias y Emmanuel Guigon, pp. 236-238.

[46] Rothko, M. (2004b), Paredes de luz. Catálogo de la exposición en el Museo Guggenheim Bilbao (8 de junio al 24 de octubre de 2004). Bilbao: Edición FMGB Museo Guggenheim Bilbao, p. 18.

[47] Breslin, J. E. B. (1993), Mark Rothko. A Biography. Chicago: The University of Chicago Press (book edition, 1998), p. 356.

[48] Olmo, S. (ed.). (2014), Colección $M^{a}$ Josefa Huarte. Abstracción y modernidad. Pamplona: Museo Universidad de Navarra.

[49] Whitman, W. (1955), Hojas de hierba [Leaves of Grass], Barcelona: Mayol Pujol.

[50] Rothko, M. (2000), Mark Rothko. Catálogo de la exposición en la Fundació Joan Miró (25 de noviembre al 28 de enero de 2001). Barcelona: Edición Fundació Joan Miró, p. 52.

\section{Biography}

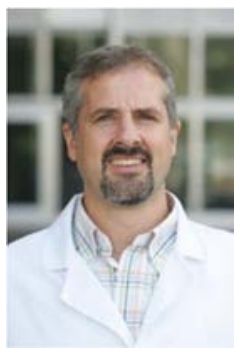

Fernando Echarri Iribarren holds a degree in Biological Sciences (University of Navarra, 1989) and $\mathrm{a} \mathrm{PhD}$ in Environmental Education (University of Navarra, 2007). He teaches in the following areas: "Museum education", "Ecology", "Environmental Impact Assessment", "University Master's Degree in Higher-Education Teaching" and Master's Degree in "Biodiversity, Landscape and Sustainable Management". His interests include significant learning experiences and significant life experiences. He has published numerous books and articles on nature and art.

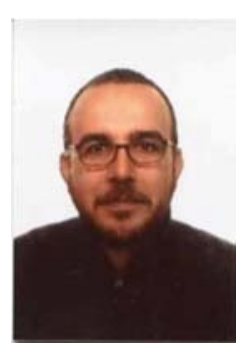

Emilio Varela Froján is an architect (1995), painter, poet and writer. $\mathrm{PhD}$ from the University of the Basque Country (UPV/EHU) - in Architecture for the programme "Idea, form and matter" (2011) and in Philosophy for the programme "Philosophy in a global world" (2015) -, has published and gave workshops on thought and creation and participated as a speaker in several international conferences on art and architecture. 